DOI https://doi.org/10.30525/978-9934-26-073-5-2-59

\title{
МІЖКУЛЬТУРНА КОМУНІКАЦІЯ ЯК СКЛАДНИК ПРОФЕСІЙНОЇ КОМПЕТЕНТНОСТІ ФАХІВЦІВ ФАРМАЦЕВТИЧНОЇ ГАЛУЗІ
}

\author{
Козаченко Г. В. \\ кандидат педагогічних наук, \\ викладач української мови \\ Житомирського базового фармацевтичного фахового коледжу \\ Житомирської обласної ради \\ Процюк І. $\mathbf{E}$. \\ кандидат педагогічних наук, \\ викладач іноземної мови \\ Житомирського базового фармацевтичного фахового коледжу \\ Житомирської обласної ради \\ м. Житомир, Украӥна
}

Швидкоплинність і швидкозмінність глобальних процесів суспільного розвитку, за яких останнім часом спостерігається тенденція до зростання міжнародних зв'язків і соціокультурної взаємодії з представниками інших національностей i культур, обумовлює необхідність модернізації змісту сучасної освіти та забезпечення якості підготовки майбутніх спеціалістів, зокрема фармацевтичних, на рівні міжнародних вимог. Пріоритетності набуває підготовка мобільних і компетентних фахівців фармацевтичної галузі, здатних стати конкурентоспроможними, різнобічно розвиненими, ініціативними та впевненими в собі особистостями, які вмітимуть прогнозувати тенденції соціальних змін, передбачати вектор розвитку суспільства, вирішувати проблеми, ефективно здійснювати професійну діяльність, орієнтуватися в сучасних умовах та здійснювати комунікацію на міжнародному рівні.

Протягом останніх десятиліть намітилася тенденція до зміщення фокусу фармацевтичної діяльності, яка первинно була зосереджена на забезпеченні ліками, на надання допомоги пацієнтові. Тож, роль фармацевтичного працівника еволюціонувала, і він перетворився з того, хто виготовляє та продає лікарські засоби, на постачальника послуг та інформації. Розвинутий рівень навичок міжкультурної комунікації фармацевтів $є$ складовою їхньої професійної компетентності. 
Здійснимо теоретичний аналіз поняття міжкультурної комунікації.

Міжкультурна комунікація - це складне, комплексне явище, яке включає різноманітні напрямки і форми спілкування між окремими індивідами, групами, які належать до різних культур.

Процес міжкультурної комунікації є специфічна форма діяльності, яка передбачає знання іноземних мов, матеріальної і духовної культури іншого народу, релігії, цінностей, моральних установок, світоглядних уявлень і т. д., в сукупності визначають модель поведінки партнерів 3 комунікації. Тільки поєднання цих двох видів знання - мови і культури забезпечує ефективне та плідне спілкування, служить основою ефективної міжкультурної комунікації.

Предметом міжкультурної комунікації $\epsilon$ контакти, які відбуваються на різних рівнях, в різній аудиторії, в двосторонньому, багатосторонньому, глобальному аспектах [1].

Метою міжкультурної комунікації має бути створення умов для розвитку конструктивного діалогу, рівноцінного стосовно представників інших культур.

Професійна діяльність фармацевта відповідає процесу, предмету, меті міжкультурної комунікації і вимагає практично постійного спілкування, основною метою якого $є$ бажання бути зрозумілим, що передбачає необхідність максимально повно і точно донести необхідну і важливу інформацію, знання і досвід до відвідувачів аптеки, іноземних партнерів, колег тощо. Це вказує на те, що ефективність спілкування залежить від рівня взаєморозуміння між співрозмовниками. Помилки та конфлікти, спричинені відмінностями вербальних і невербальних кодів у носіїв різних категорій населення, що можуть виникнути у процесі комунікації, мають істотний вплив на діяльність, службову кар'єру і психічний стан фахівця. Причиною цього, найчастіше, є низька культура спілкування, пов'язана 3 нестачею сформованих знань про культурні особливості, ціннісні орієнтації, норми поведінки й етикету, традиції, стилі життя різних категорій населення, відтак, з відсутністю основи для розвитку необхідних комунікативних умінь і навичок. Саме тому, для досягнення взаєморозуміння в процесі комунікації необхідна певна сукупність знань, навичок і умінь, загальних для всіх співрозмовників.

Інтерес до проблематики міжкультурної комунікації в системі діяльності «людина - людина», до якої безпосередньо належить й професія фармацевта, набув упродовж останнього часу сталого характеру і зумовлюється низкою обставин як власне теоретичного, так i практичного порядку. 
Спілкування та культура взаємопов'язані між собою i мають здатність впливати один на одного. Це переплетення створює міжкультурне спілкування, яке служить способом розуміння особливостей представників різних категорій населення, продуктивної взаємодії між людьми, встановлення і підтримки контактів, засвоєння та накопичення знань, досвіду, цінностей і способів діяльності, формування людини як особистості.

Професійна компетентність фармацевта специфічна, вона передбачає оволодіння системою знань, умінь, навичок та здібностей, якостей особистості щодо досягнення мети або досягнення позитивного результату в процесі навчально-виробничої діяльності. Адже фармацевтичні працівники належать до сфери професійної діяльності 3 підвищеною комунікативною відповідальністю, працюють з людьми похилого віку, хворими, іноземцями та іншими категоріями, 3 якими необхідно встановити контакт, уміти вести бесіду, надавати поради та рекомендації щодо вибору й застосування лікарських препаратів, ураховувати їхній менталітет, мову, рівень культури тощо [3].

Варто зауважити, що оскільки в процесі виконання своїх безпосередніх обов'язків, фармацевт взаємодіє з представниками різних категорій населення, саме тому йому необхідно мати не лише міцні професійні знання та високий рівень професійної компетентності, а й володіти необхідним мінімумом соціокультурних знань, мистецтвом спілкування, дотримуватися моральних принципів і норм поведінки та етикету.

Важливу роль в міжкультурній комунікації саме фармацевтів відіграють специфічні символи, стереотипи, упередження, національний мовленнєвий етикет. Культура спілкування $є$ одним із пріоритетних компонентів професійної культури фахівців фармацевтичної галузі. Вона синтезує у собі комплекс знань, цінностей, зразків поведінки, характерних для ситуацій ділового спілкування, а також умінь гнучко реалізовувати їх на практиці з метою забезпечення ефективності спільної діяльності [2, с. 27]. Оскільки висока культура фармацевтичного обслуговування характеризується рівнем розвитку комунікативних знань і вмінь, фармацевти повинні виховувати в собі культуру спілкування, дотримуватися культурних, національних та соціальних правил мовно-комунікативної поведінки, притаманних тим чи іншим націям i національним спільнотам.

В свою чергу, виховання культури спілкування містить сукупність комунікативних навичок, що дозволяють легко вступати в контакти, зберігаючи в процесі спілкування самоконтроль. Спілкування 
3 відвідувачами аптек, колегами потребує особливого терпіння, ввічливості, співчуття. У зв'язку з цим набувають особливого значення такі якості, як комунікабельність й емоційна усталеність, виховання, професійні навички, вміння пояснити, тактовність, ерудиція та ін.

Грунтуючись на вищевикладеному, можна стверджувати, що сформовані знання та навички міжкультурної комунікації фахівцівфармацевтів сприятимуть ефективній професійній діяльності, а саме:

1) надання кваліфікованої, якісної, доступної та своєчасної фармацевтичної допомоги представникам різних категорій населення;

2) формування довіри до професійної діяльності фармацевтів та підвищення статусу й іміджу фармацевтичної професії в суспільстві;

3) забезпечення гарантій безпеки застосування лікарських засобів та виробів медичного призначення різними категоріями населення;

4) налагодження професійних зв'язків 3 іноземними партнерами, фармацевтичними компаніями; просування ліків закордонного виробництва на вітчизняному ринку;

5) дотримання норм фармацевтичної етики та деонтології, постійне підвищення рівня професійних знань, умінь та навичок.

\section{Література:}

1. Боголюбова Н.М., 2017. Поняття міжкультурної комунікації. URL: https://stud.com.ua/90288/kulturologiya/ponyattya_mizhkulturnoyi_ komunikatsiyi2

2. Галицька, М. М., 2014. Міжкультурна комунікація та ії значення для професійної діяльності майбутніх фахівців. Освітологічний дискурс. № 2. C. 23-32. URL: http://nbuv.gov.ua/UJRN/osdys_2014_2_5

3. Кайдалова, Л.Г., 2010. Професійна підготовка майбутніх фахівиів фармачевтичного профілю у вищих навчальних закладах: монографія. Х.: НФаУ, 364 c. 